
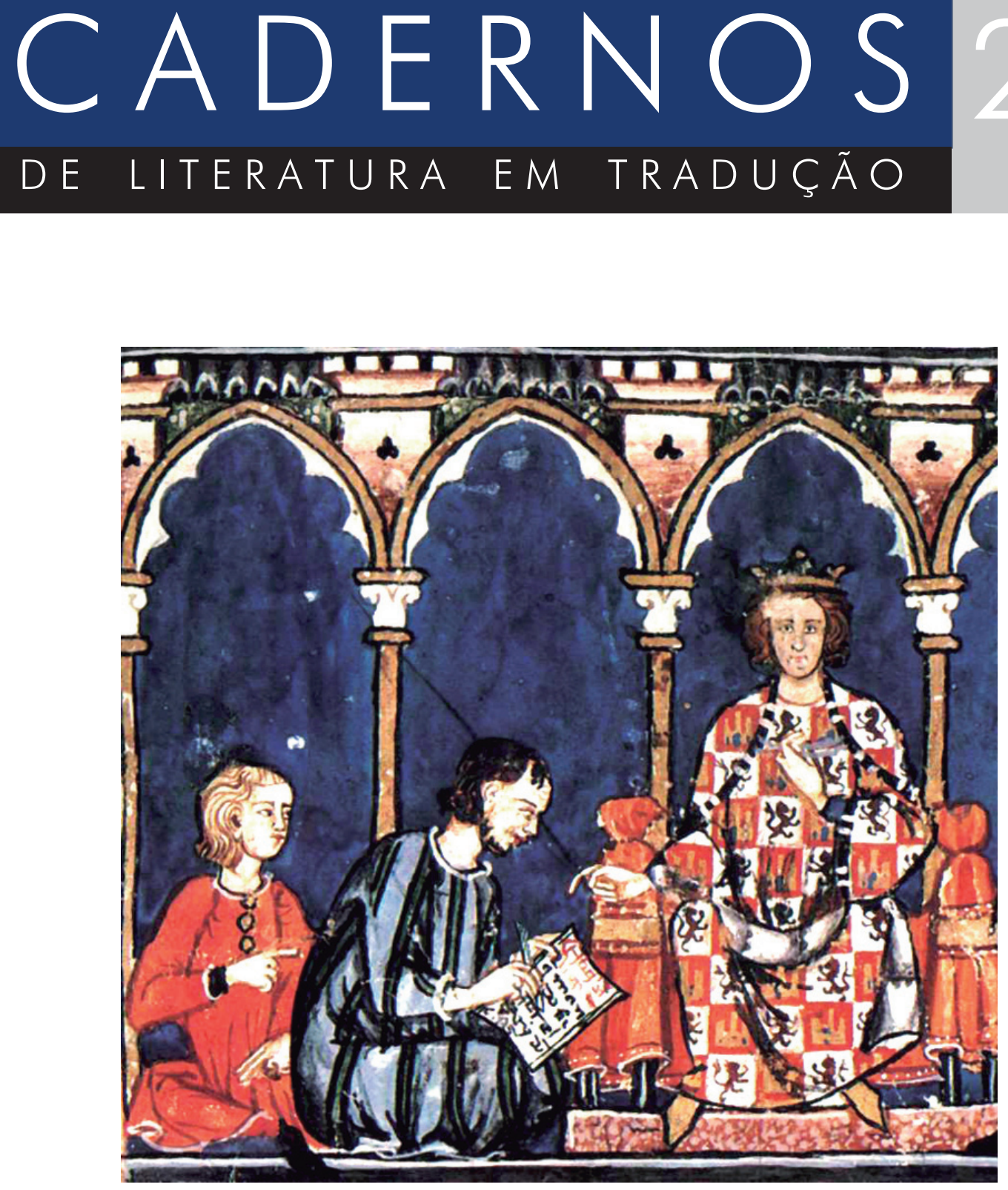

Tradutores da chamada Escola de Toledo com Afonso $X$ de Castela 


\title{
Afinidades improváveis: à guisa de introdução
}

\author{
Pedro Mohallem ${ }^{1}$
}

Após uma sequência de quatro números temáticos - "Especial 100 Grandes Poemas da Índia", "Especial 'Os Russos Estão Chegando", "Especial Autoras Latino-Americanas" e "Especial Literatura Nórdica" -, a Cadernos de Literatura em Tradução apresenta mais um número de caráter geral. A presente edição é vasta no número de páginas como em contribuições para os estudos tradutológicos: são traduzidos verso, prosa e teatro; poemas, contos, novelas e crônicas; traduzem-se para o português obras do inglês, espanhol, híndi, náhuatl, russo, entre outros; o português, todavia, não é a única língua-meta, figurando também traduções para o inglês e chinês. Com o texto traduzido sempre acompanhado de uma descrição do percurso tradutório, o leitor não se verá desprovido de notas explicativas e de cunho biográfico acerca dos autores estrangeiros. Além das traduções comentadas, este número geral traz ensaios e artigos dedicados à história e crítica da tradução, e a já tradicional e esperada entrevista com a tradutora. Em uma comunhão de vozes separadas por séculos e oceanos, o ato tradutório faz com que se percebam afinidades superiores aos domínios da literatura - sem que esta seja, absolutamente, ignorada.

No campo da tradução poética, Sara Lelis de Oliveira apresenta tradução inédita para o português de dois cantos dos Cantares Mexicanos, escritos em náhuatl clássico, língua indígena franca registrada em latim no contexto da catequização. A autora debruça-se sobre as deturpações de sentido decorrentes da intervenção do pensamento cristão sobre os elementos culturais e religiosos presentes nos textos transcritos.

1 Poeta e tradutor. Bacharel em Letras: Português-Inglês e Mestrando em Estudos da Tradução pela Universidade de São Paulo. 
Pedro Augusto Pinto traduz e comenta "A Morte de um Poeta", estreia literária de Mihkail Iúrevitch Lérmontov, um dos mais importantes poetas russos do século XIX, fornecendo um breve panorama do contexto histórico e cultural no qual o autor e a obra traduzida se inserem.

Marina Darmaros traduz dois poemas de Semion Nadson, poeta da Rússia Imperial, não sem antes propor um sumário biográfico do autor e de sua fortuna crítica, descrita como um "legado contraditório", devido à falta de consenso entre os estudiosos acerca do caráter de sua obra, bem como de sua vida.

Luciane Bonace traduz e comenta sete poemas escritos durante a Segunda Guerra Mundial, mais especificamente por crianças e jovens no campo de concentração de Terezín. Traduzidos do tcheco para o português, os poemas contribuem para que se entenda o holocausto na visão dos mais jovens, que, apesar da pouca idade, mostravam-se bastante conscientes da situação em que viviam.

Alan Cardoso da Silva analisa e traduz para o português três poemas de Samuel Beckett, escritos durante o avanço do movimento nazista na França, e ainda inéditos no Brasil. A escolha dos poemas se deu a fim de se rememorar o pensamento antifascista do dramaturgo.

Cláudia Tavares Alves propõe tradução e análise de três poemas de Franco Fortini, que se destacou no período de intensa atividade intelectual da Itália posterior ao fascismo.

Marina Leivas Waquil traduz e comenta "Malinche", de Rosario Castellanos, autora mexicana ainda inédita no Brasil. Sua proposta se assenta na reflexão da tradução feminista de Barbara Godard.

Li Li analisa sua tradução para o chinês de quatro poemas do escocês Edwin Morgan, considerado o mais importante poeta de seu país. Baseando-se na obra reunida por James McGonigal, comenta as implicações funcionais de suas escolhas ao transpor o texto para um público pouco familiarizado com a obra de Morgan.

Sofia Lopes traduz e comenta dois poemas de Charles Bukowski, "an almost made up poem", do livro Love is a Dog from Hell (1977), e "eulogy to a hell of a dame", de War All the Time (1984), buscando preservar o efeito estilístico dos textos e seu equilíbrio entre o lírico e o brutal, característica marcante na obra do poeta.

Na prosa, João Cândido Maia comenta sua tradução da narrativa "Unverhofftes Wiedersehen", de Johann Peter Hebel, a partir da leitura de Walter Benjamin, justificando as soluções tradutórias aplicadas a fim de aproximar o leitor da tradução da posição do leitor visado por Hebel. 
Davi Silva Gonçalves traduz crônica do autor nicaraguense Rubén Darío intitulada "Edgar Allan Poe", com base em duas premissas: manter os elementos responsáveis pelo ritmo acelerado ou "elétrico" do texto e enfatizar seu caráter hipertextual e híbrido, lidando com as inúmeras referências literárias e extraliterárias presentes na narrativa.

Gisele Lemos traduz do hindi e comenda "O teste", conto de Munshi Premchand inspirado no episódio da invasão de Delhi pelo monarca iraniano Nadir Shah em 1739. Objetivando transmitir a ideia de ser a mulher a responsável por preservar a tradição e a moral na sociedade indiana, o texto é repleto de estereótipos de gênero, e seu estilo simples e objetivo é uma das principais marcas preservadas pela tradutora.

Aline Duvoisin e Juliana Steil traduzem o conto "El cazador de orquideas", do argentino Roberto Arlt, situando-o no projeto criativo do autor. A proposta tradutória de Steil e Duvoisin é voltada para a preservação de marcas da oralidade e segue na esteira dos estudos de Britto (2012).

Simone Pereira Gonçalves apresenta tradução do romance urbano Blutsbrüder (Irmãos de Sangue), de autor desconhecido, publicado pela primeira vez em 1932 e censurado pela ditadura nazista. Sua proposta de tradução se aproxima da teoria ilusionista de Levý (1969), no sentido de que objetiva transmitir ao leitor da tradução a sensação de estar lendo uma obra originalmente escrita no idioma de chegada.

Ana Lúcia Kfouri traduz o excerto inicial da novela Of mice and men, de John Steinbeck, motivada pelo desafio de preservar a variação de registro da língua entre o narrador e as personagens, de modo que essa distinção fosse transposta de modo coerente no sistema de chegada.

Isadora Fortunato comenta sua tradução de "Passing", conto de Langston Hughes, analisando como o autor se aproveita do gênero epistolar para mesclá-lo ao literário e investigando, à luz de teóricos como Berman, que postura tradutória deve ser assumida para que o texto traduzido abarque não apenas o valor semântico das palavras, mas toda a cadeia de significados do texto, contemplando a distinção entre língua falada e escrita e aproximando o leitor da tradução do tipo de crítica pretendida pelo texto-fonte.

Dinaura Julles traduz e comenta "Unguided Tour", conto de Susan Sontag, autora conhecida principalmente por seu trabalho no jornalismo literário e ainda inédita no Brasil como contista. Em "Turismo sem Guia”, a tradutora demonstra que foi possível sustentar a polissemia do texto de Sontag a partir da proposta de desconstrução de Jacques Derrida. 
Lívia Martuscelli apresenta tradução do conto Civil Peace, do autor nigeriano Chinua Achebe, discutindo sobre alguns dos principais dilemas de tradução, dentre eles o modo de se traduzir os diálogos em pidgin da Nigéria.

Nylcéa Thereza de Siqueira Pedra traduz, da escritora mexicana Socorro Venegas, o conto "O vazio". O texto narra com um estilo conciso e certeiro a crise existencial de uma mãe incapaz de estabelecer vínculos afetivos com o seu bebê recém-nascido. Um dos focos da análise de Siqueira Pedra é justificar as escolhas lexicais em sua tradução, como por exemplo a motivação em traduzir "bueco" e "oquedad" por "vazio".

Em seu artigo, Mary Anne Warken e Alison Silveira, orientados pela Professora Doutora Odile Cisneros, apresentam duas propostas de tradução comentada do conto "Solo", do escritor chileno Astete Cuadra: Warken o traduz para o português em colaboração com o colega e a orientadora (" $A$ sós"), e Silveira o traduz para o inglês ("Alone").

Após breve contextualização da narrativa do escritor argentino Federico Falco à luz de Drucaroff (2011) e Sarlo (2012), Rafael Bezerra traduz o conto “El pelo de la Virgen", ressaltando sua estética "desprovida de recursos excepcionais, mas que narra o excepcional".

No teatro, Fernando Bustamante traduz o prólogo da peça The Case of Clyde Griffiths, de Erwin Piscator, ainda inédita em língua portuguesa e parte de sua pesquisa de doutorado, destacando os atributos que a configuram como parte do teatro épico.

Marcelo Paiva de Souza traduz fragmento da peça Świadkowie albo Nasza Mała Stabilizacja (“As Testemunhas ou Nossa Pequena Estabilização”), do escritor polonês Tadeusz Różewicz, ressaltando seu valor estético, político e intercultural. Sua tradução é amparada por dois vetores, os quais Paiva descreve como "sua espessura própria como gênero literário e a intrínseca pulsão cênica que o atravessa".

Nos quadrinhos, Mariana Doninelli analisa, à luz dos estudos de van den Broeck (1981) e Lakoff e Johnson (2002), como se dá a tradução de metáforas em dez tirinhas do Garfield, de Jim Davis, distinguindo paráfrases de traduções literais e estudando possíveis afinidades entre os sistemas conceptuais das culturas estadunidense e brasileira.

No campo da história da tradução, Francisco Manhães Monteiro analisa criação, censura e o papel da oralidade nas traduções produzidas pelo grupo conhecido como a Escola de Tradutores de Toledo, atuante na Espanha medieval. 
14 Apresentação.

Fechando o número, Mário Coutinho entrevista Aurora Bernardini, tradutora, crítica literária e professora titular do Departamento de Letras Orientais da Universidade de São Paulo. 